ISSN 0258-7122

Bangladesh J. Agril. Res. 37(3): 369-376, September 2012

\title{
BREEDING FOR IMPROVING FIBRE YIELD AND GREEN BIOMASS IN SUNNHEMP (Crotalaria juncea L.) GERMPLASM
}

\author{
D. KUMAR ${ }^{1}$, M.K. TRIPATHI, S.K. SARKAR \\ ARPITA DAS AND SANJOY SHIL
}

\begin{abstract}
Fifteen genetically diverse parental genotypes of sunnhemp belonging to different geographical origin were assessed to evaluate general and specific combining ability of parents and cross combinations, respectively, for selecting the superior parent combination. For this, fifteen parents and their $105 \mathrm{~F}_{1} \mathrm{~s}$ were grown in a Randomized Block Design (RBD) with three replications and data were collected in respect of plant height, base diameter, green weight, fibre weight, stick weight and fibre percentage. Analyses of variances of diallel revealed that there was predominance of specific combining ability (sca) in almost all the characters except fibre percentage and general combining ability (gca) was significant only in case of plant height. From the gca effect of parents it can be seen that K-12 (B) and SUIN-056 showed good promise as general combiners and able to produce better cross combinations. However only one cross combination viz. SUIN-056 $\times$ SUIN-074 was recorded positive sca effects for all the characters. This cross combination along with SUIN-001 $\times$ SUIN-056 exhibited positive heterosis over the better parents in all the characters studied and can be used in breeding programme for producing improved sunnhemp population. Further, to exploit fully both additive and nonadditive variances present in this population, random as well as chain crossing among the promising crosses was found effective to exploit both additive and fixable epistatic effects.
\end{abstract}

Keywords: Combining ability, heterosis, gene action, fibre yield, green biomass and sunnhemp.

\section{Introduction}

Sunnhemp (Crotalaria juncea L.) is an important multipurpose crop grown all over tropics for fibre, green manure and fodder purpose (Kundu, 1964). It is one of the earliest and most distinctly named bast fibre of India next to jute. It is well known for its coarse textured fibre which is used for manufacturing of wide variety of products like paper, marine cordage, rope, string and fishing net, coarse fabric for hose pipe, belting and canvas, tissue paper, bank currency, rugs, carpets, webbing, etc. Sunnhemp being leguminous crop enriches the soil by fixing atmospheric nitrogen to the extent of $100 \mathrm{~kg} / \mathrm{ha}$ (Pradhan et al., 1999). It is also effective as a cover crop and preventing a build up of root knot nematode.

\footnotetext{
${ }^{1}$ Sunnhemp Research Station, Pratapgarh, U. P. and Central Research Institute for Jute and Allied Fibres, Barrackpore 700 120, West Bengal, India.
} 
The concept of combining ability is important in designing plant breeding programme. Two types of combining ability, general and specific, have been recognized in quantitative genetics. The knowledge of gene action and combining ability helps in proper understanding of inheritance of characters in selection of suitable parents for hybridization programme and for obtaining desirable segregants. Sunnhemp being in the preliminary stage of breeding, information on good combiner is lacking, hence the present investigation was carried out to evaluate general combining ability of parents and specific combining ability of cross combinations, selecting the superior parent combinations and producing improved sunnhemp population with higher fibre and green biomass yield.

\section{Materials and Method}

Fifteen genetically diverse parental genotypes of sunnhemp belonging to different geographical origin were crossed in diallel matting design excluding the reciprocals. These genotypes include K-12 (Y), K-12 (B), SH-4, T-6, SUIN-001, SUIN-007, SUIN-036, SUIN-056, SUIN-061, SUIN-070, SUIN-071, SUIN-074, SUIN-075, SUIN-087, and SUIN-092. The fifteen parents and their $105 \mathrm{~F}_{1} \mathrm{~s}$ were grown in a Randomized Block Design (RBD) with three replications. The row length was $3 \mathrm{~m}$ and row to row and plant to plant distance were $30 \mathrm{~cm}$ and $5-7 \mathrm{~cm}$ respectively. Data on ten plants per entry were recorded in respect of plant height, base diameter, green weight, fibre weight, stick weight, and fibre percentage. The proportion of fibre weight of ten plants to fibre weight plus stick weight of these ten plants or the fibre percentage was considered as an approximate measure of harvest index. Fibre percentage was transformed to angular values for final analysis. The experimental data were analyzed following Model 1 and Method 2 of Griffing (1956).

Five superior parents viz. SUIN-056, SUIN-074, SUIN-001, K-12 (B), and $\mathrm{K}-12(\mathrm{Y})$ were selected on the basis of combining ability and heterosis over better parent. Chain crossing and random matting were done among these parents and crossed seeds as well as random matted open pollinated seeds were harvested separately. In the next season, populations from these seeds were grown with check variety, K-12 (Y), in R.B.D. with eight replications.

\section{Results and Discussion}

General analysis of variances for six characters showed that parents were highly significant for plant height, while crosses were significant for plant height and stick weight (Table 1). On the other hand, parent vs hybrids interaction was highly significant for almost all the characters except plant height. 
Table 1. Analysis of variance for six characters in $15 \times 15$ half diallel cross in sunnhemp.

\begin{tabular}{lccc|c|c|c|c|c}
\hline $\begin{array}{l}\text { Source of } \\
\text { variation }\end{array}$ & df & $\begin{array}{c}\text { Plant } \\
\text { height }\end{array}$ & $\begin{array}{c}\text { Base } \\
\text { diameter }\end{array}$ & $\begin{array}{c}\text { Green } \\
\mathrm{wt}\end{array}$ & $\begin{array}{c}\text { Fibre } \\
\mathrm{wt}\end{array}$ & $\begin{array}{c}\text { Stick } \\
\mathrm{wt}\end{array}$ & $\begin{array}{c}\text { Fibre } \\
\text { (\%) }\end{array}$ \\
\hline Replications & 2 & 10.85 & $0.195^{* *}$ & 97.65 & 2.36 & 67.64 & $10.25^{*}$ \\
Treatments & 119 & $272.22^{* *}$ & 0.02 & $1195.2^{* *}$ & $1.71^{*}$ & $159.66^{* *}$ & 2.65 \\
Parents & 14 & $481.93^{* *}$ & 0.02 & 912.66 & 1.30 & 99.91 & 2.62 \\
Hybrids & 104 & $246.1^{*}$ & 0.02 & 956.64 & 1.48 & $131.71^{*}$ & 2.43 \\
$\begin{array}{l}\text { Parent Vs } \\
\text { Hybrids }\end{array}$ & 1 & 52.15 & $0.543^{* *}$ & $29961.19^{* *}$ & $31.74^{* *}$ & $3903.32^{* *}$ & $25.48^{* *}$ \\
Error & 238 & 44095.22 & 0.02 & 819.33 & 1.20 & 99.44 & 2.65 \\
\hline
\end{tabular}

**, * Significant at $5 \%$ and $1 \%$, respectively.

Analysis of variances of diallel (Table 2) showed that general combining ability (gca) was significant only for plant height, while specific combing ability (sca) was significant for almost all the characters except fibre percentage. This indicated that the inheritance of the character plant height was controlled by both additive and non-additive gene actions, while base diameter, green weight, fibre weight and stick weight were controlled by non-additive gene action. Since sunnhemp is an obligatory cross pollinated crop due to self-incompatibility there is preponderance of non additive gene action i.e. dominance and epistatic effect in most of the characters. Similar results have been reported in different crops (Matzinger et al., 1959; Liang, 1967; Paroda and Joshi, 1970 and Patil and Chopda, 1981).

Table 2. Analysis of variance for six characetrs in $15 \times 15$ half diallel cross in sunnhemp.

\begin{tabular}{c|c|c|c|c|c|c|c}
\hline $\begin{array}{c}\text { Source of } \\
\text { variation }\end{array}$ & df & $\begin{array}{c}\text { Plant } \\
\text { height }\end{array}$ & $\begin{array}{c}\text { Base } \\
\text { diameter }\end{array}$ & $\begin{array}{c}\text { Green } \\
\text { wt }\end{array}$ & $\begin{array}{c}\text { Fibre } \\
\text { wt }\end{array}$ & $\begin{array}{c}\text { Stick } \\
\text { wt }\end{array}$ & $\begin{array}{c}\text { Fibre } \\
(\%)\end{array}$ \\
\hline GCA & 14 & $166.55^{* *}$ & 0.00 & 310.14 & 0.41 & 28.03 & 0.44 \\
SCA & 105 & $80.63^{* *}$ & $0.00693^{*}$ & $410.17^{* *}$ & $0.59^{* *}$ & $56.58^{* * *}$ & 0.94 \\
Error & 238 & 61.76 & 0.01 & 273.11 & 0.40 & 33.15 & 0.88 \\
\hline
\end{tabular}

**, * Significant at $5 \%$ and $1 \%$, respectively.

The gca effects of the parents were presented in Table 3. It can be found that out of 15 parents, K-12 (B) and SUIN- 056 were the desirable combiners for all the traits as these two parents showed positive or significantly positive gca effects consistently for all the characters. Thus, K-12 (B) and SUIN-056 showed good promise as general combiners since they were controlled mostly by additive gene effect. However, T-6 and SUIN-075 recorded positive gca effect for fibre weight and fibre percentage. Thus, considering fibre yield and other yield 
components, it was observed that K-12 (B) and SUIN-056 were good general combiners not only for fibre yield but also for many of fibre yield contributing characters. This indicated the preponderance of additive gene effects in these two parents. According to Sprague and Tatum (1942), general combining ability is due to genes which are largely additive in their effects. Parent with high gca were found to produce high yielding cross combinations (Coyle and Smith, 1997; Hassan et al., 2000 and Lukonge et al., 2007).

Table 3. General combining ability (gca) effects of the parents for various characters in a $15 \times 15$ half diallel cross of sunnhemp.

\begin{tabular}{c|c|c|c|c|c|c}
\hline Variety & Plant height & $\begin{array}{c}\text { Base } \\
\text { diameter }\end{array}$ & Green wt & Fibre wt & Stick wt & Fibre (\%) \\
\hline 1 & 3.352 & 0.017 & 5.817 & 0.035 & 0.701 & -0.161 \\
2 & $5.460^{*}$ & 0.017 & 5.379 & 0.287 & 2.062 & 0.085 \\
3 & -0.030 & -0.011 & -4.944 & -0.079 & -1.65 & 0.195 \\
4 & -0.046 & -0.002 & -0.752 & 0.05 & -0.805 & 0.194 \\
5 & -6.293 & 0.007 & 0.35 & 0.033 & 0.892 & -0.004 \\
6 & -1.932 & 0 & 2.846 & -0.167 & 0.419 & -0.29 \\
7 & 0.827 & -0.002 & 5.066 & -0.083 & -0.138 & -0.142 \\
8 & 2.623 & 0.018 & 2.854 & 0.285 & 2.017 & 0.073 \\
9 & -1.22 & 0.019 & 1.799 & 0.113 & 1.513 & -0.198 \\
10 & 3.035 & -0.009 & -2.972 & -0.111 & -1.622 & 0.075 \\
11 & -3.316 & -0.006 & -7.017 & -0.283 & -1.508 & -0.143 \\
12 & 2.652 & -0.001 & 3.460 & 0.076 & 0.382 & -0.031 \\
13 & -0.667 & -0.022 & -2.964 & 0.021 & -0.414 & 0.26 \\
14 & -0.467 & -0.02 & -3.091 & -0.075 & -0.338 & -0.002 \\
15 & $-3.977 *$ & -0.006 & -5.830 & -0.101 & -1.51 & 0.091 \\
\hline
\end{tabular}

* Significant at $1 \%$ level

Out of 15 parents which produce 105 cross combinations in $15 \times 15$ half diallel, only eight parents showed positive gca effects for fibre weight. These eight parents were selected and their all possible combinations were tested for specific combining ability effects and heterosis study. Among 28 crosses involving eight parents, only one cross combination viz. SUIN-056 $\times$ SUIN-074 was recorded positive sca effects for all the characters under study. Besides this cross combination, five cross combinations viz. K-12 (Y) $\times$ T-6, K-12 (B) $\times$ SUIN-074, T-6 $\times$ SUIN-061, SUIN-001 $\times$ SUIN-056, and SUIN-061 $\times$ SUIN075 exhibited positive sca effects for fibre weight and fibre percentage. According to Rawlings and Thompson (1962), sca effect is due to genes with dominance and epistatic effect. A comparison of the sca effects of the crosses and the gca effects of the parents were not related to the sca effects of their crosses. Higher gca of parent does not necessarily confer higher sca and the gca and sca were independent (Khan et al., 2007b). 
Table 4. Specific combining ability (sca) effects of 28 crosses for six characters in sunnhemp.

\begin{tabular}{|c|c|c|c|c|c|c|}
\hline Crosses & $\begin{array}{l}\text { Plant } \\
\text { height }\end{array}$ & $\begin{array}{c}\text { Base } \\
\text { diameter }\end{array}$ & $\begin{array}{c}\text { Green } \\
\mathrm{wt}\end{array}$ & $\begin{array}{c}\text { Fibre } \\
\text { wt }\end{array}$ & $\begin{array}{c}\text { Stick } \\
\text { wt }\end{array}$ & Fibre $(\%)$ \\
\hline $\mathrm{K}-12(\mathrm{Y}) \times \mathrm{K}-12(\mathrm{~B})$ & 6.314 & -0.001 & -2.297 & -0.419 & -1.762 & -0.423 \\
\hline $\mathrm{K}-12(\mathrm{Y}) \times \mathrm{T}-6$ & 0.486 & -0.086 & -23.966 & 0.319 & -4.662 & 1.661 \\
\hline K - $12(Y)$ x SUIN - 001 & 8.400 & -0.029 & 9.599 & 0.636 & 1.409 & 0.489 \\
\hline K - $12(Y) \times$ SUIN - 056 & -6.182 & -0.039 & 5.162 & -0.183 & 1.483 & -0.441 \\
\hline K - $12(\mathrm{Y})$ x SUIN - 061 & -10.006 & 0.063 & 8.450 & 0.056 & -0.513 & 0.163 \\
\hline K - $12(\mathrm{Y}) \times$ SUIN -074 & 0.955 & 0.039 & 13.289 & 0.260 & 2.285 & -0.087 \\
\hline K - $12(\mathrm{Y}) \times$ SUIN - 075 & -2.225 & 0.080 & -3.921 & -0.152 & -0.119 & -0.259 \\
\hline $\mathrm{K}-12(\mathrm{~B}) \times \mathrm{T}-6$ & -5.955 & 0.038 & 9.072 & -0.068 & 1.711 & -0.471 \\
\hline K - 12 (B) x SUIN - 001 & 19.459 & 0.161 & 32.970 & -0.250 & 8.881 & -1.817 \\
\hline K - 12 (B) x SUIN - 056 & -6.790 & -0.172 & -54.101 & -1.803 & -17.044 & 0.736 \\
\hline K - 12 (B) x SUIN - 061 & -4.447 & 0.026 & 9.687 & 0.003 & 3.526 & -0.56 \\
\hline K - 12 (B) x SUIN - 074 & -9.153 & -0.077 & -35.174 & 0.240 & -9.642 & 2.947 \\
\hline K - 12 (b) x SUIN - 075 & -10.366 & -0.053 & -5.950 & -0.838 & -4.946 & -0.761 \\
\hline T - 6 x SUIN - 001 & 6.565 & 0.051 & 8.568 & -0.046 & -0.986 & -0.072 \\
\hline T - 6 xSUIN - 056 & -10.784 & 0.037 & 6.930 & 0.001 & 3.589 & -0.833 \\
\hline T - 6 x SUIN - 061 & -5.841 & 0.009 & 5.985 & 0.074 & 0.160 & 0.051 \\
\hline T -6 x SUIN - 074 & 8.187 & -0.038 & -16.409 & -0.156 & -3.076 & 0.495 \\
\hline T - 6 x SUIN - 075 & -11.327 & 0.116 & 11.381 & 0.966 & 9.787 & -0.617 \\
\hline SUIN - 001 x SUIN - 056 & -9.204 & 0.024 & -0.772 & 0.115 & -2.607 & 0.212 \\
\hline SUIN - 001 x SUIN - 061 & -5.627 & -0.001 & -0.517 & 0.591 & 8.597 & -0.674 \\
\hline SUIN - 001 x SUIN - 074 & 5.434 & 0.112 & 39.689 & 1.728 & 14.628 & -0.131 \\
\hline SUIN - $001 \times$ SUIN - 075 & 9.587 & 0.006 & 1.579 & 0.117 & 10.858 & -1.636 \\
\hline SUIN - 056 x SUIN - 061 & 13.890 & 0.059 & 13.146 & 0.405 & 3.438 & -0.134 \\
\hline SUIN - 056 x SUIN - 074 & 6.518 & 0.152 & 52.452 & 2.409 & 17.736 & 0.092 \\
\hline SUIN - 056 x SUIN - 075 & 3.337 & 0.059 & 1.942 & 0.397 & 3.932 & -0.466 \\
\hline SUIN - 061 x SUIN - 074 & -6.806 & -0.046 & -2.693 & -0.152 & -3.660 & 0.503 \\
\hline SUIN - 061 x SUIN - 075 & 2.247 & -0.135 & -21.003 & 0.27 & -9.264 & 2.132 \\
\hline SUIN - 074 x SUIN - 075 & -6.192 & -0.052 & -11.497 & -1.226 & -5.766 & -1.295 \\
\hline
\end{tabular}


Table 5. Percent heterosis over better parent in 28 crosses for six characters in sunnhemp.

\begin{tabular}{|c|c|c|c|c|c|c|}
\hline Crosses & Plant height & Base diameter & Green wt & Fibre wt & Stick wt & Fibre $(\%)$ \\
\hline $\mathrm{K}-12(\mathrm{Y}) \mathrm{x} \mathrm{K}-12(\mathrm{~B})$ & -0.71 & -1.45 & 0.40 & -5.41 & -3.24 & -10.58 \\
\hline K - $12(\mathrm{Y}) \times$ SUIN - 001 & 8.88 & 4.11 & 4.28 & 7.57 & 0.73 & -7.09 \\
\hline K - $12(\mathrm{Y}) \times$ SUIN - 007 & 0.62 & -10.87 & -9.63 & -14.05 & -17.50 & -3.51 \\
\hline K - $12(Y) \times$ SUIN - 056 & -5.74 & -4.11 & 3.18 & -1.62 & 3.10 & -16.63 \\
\hline K - 12 (y) x SUIN - 061 & $-8.25^{*}$ & 3.38 & 4.45 & 0.54 & -1.85 & -4.29 \\
\hline K - $12(\mathrm{Y}) \times$ SUIN - 074 & -3.39 & 0.24 & 8.12 & 2.16 & 1.45 & -0.88 \\
\hline K - 12 (B) x SUIN - 001 & 4.79 & 19.79 & 19.98 & 1.12 & 36.75 & $-23.69 *$ \\
\hline K - 12 (B) x SUIN - 007 & -1.88 & 1.06 & -17.80 & -1.12 & -6.57 & 5.01 \\
\hline K - 12 (B) x SUIN - 056 & -4.83 & -5.80 & -28.94 & -20.79 & -20.09 & -5.52 \\
\hline K - 12 (B) x SUIN - 061 & -1.65 & 7.47 & 7.35 & 6.74 & 25.90 & -12.03 \\
\hline K - 12 (B) x SUIN - 074 & -4.12 & -2.56 & -17.64 & 10.11 & -16.50 & 18.65 \\
\hline SUIN - 001 x SUIN - 007 & -1.56 & 3.58 & -1.73 & -3.90 & 1.61 & -13.56 \\
\hline SUIN - 001 x SUIN - 056 & $-9.50 *$ & 13.77 & 26.70 & 11.52 & 27.56 & -10.31 \\
\hline SUIN - 001 x SUIN - 061 & -1.65 & 4.64 & 23.22 & 24.22 & $41.65^{*}$ & -16.76 \\
\hline SUIN - 001 x SUIN - 074 & -3.18 & 11.28 & 26.91 & $37.87 *$ & 30.87 & -11.04 \\
\hline SUIN - 007 x SUIN - 056 & $-7.85^{*}$ & 5.82 & 16.02 & 10.30 & $39.00 *$ & $-22.18 *$ \\
\hline SUIN - 007 x SUIN - 061 & -2.89 & 2.06 & 11.82 & 3.73 & 16.29 & -10.97 \\
\hline SUIN - 007 x SUIN - 074 & -7.08 & 8.46 & 8.23 & -11.83 & -0.96 & -19.92 \\
\hline
\end{tabular}


Out of 28 cross combinations, only one cross combination viz. SUIN-056 $\times$ SUIN-074 recorded significantly positive heterosis over better parents for fibre weight, stick weight, and green weight and positive heterosis for base diameter. Similarly, the cross combination SUIN-001 $\times$ SUIN-056 exhibited significantly positive heterotic effect over better parent for the character fibre weight, and positive heterotis for stick weight, green weight and base diameter. On the other hand, three cross combinations viz. K-12 (Y) $\times$ T-6, K-12 (B) $\times$ SUIN-074 and T-6 $\times$ SUIN-074 showed positive effect for fibre weight and fibre percentage. Due to better sca, the heterosis was also more pronounced for yield trait. Muthu et al. (2005) mentioned that high sca effect associated with standard heterosis.

In case of sunnhemp, it will not possible to develop inbreed line through pure line selection due to its obligate cross pollinating nature which can cause severe inbreeding depression. Performance of two improved populations obtained from chain crossing of five superior cross combinations as well as random matted among the superior cross combinations grown with check variety, K-12 (Y) were presented in Table 6. It was found that the chain crossed population (JRJ 610) produced $1.90 \mathrm{q} / \mathrm{ha}$ more fibre than the check variety $(12.35 \mathrm{q} / \mathrm{ha})$. On the other hand, random matted population (JRJ 611) yielded $1.22 \mathrm{q} / \mathrm{ha}$ more fibre than the check variety. From this observation it can be concluded that chain crossed population performed the best in respect of fibre yield over the random matted population. Sunnhemp is a cross pollinated crop. Pollination is entomophilic in nature, mostly occur by bumble bee. So there is less pollination control in random matted population than the chain crossed one. As a result, the performance of random matted population was declined by admixture of inferior pollen grain.

Table 6. Performance of sunnhemp promising lines regarding fibre yield.

\begin{tabular}{c|c|c}
\hline Sl. No. & Line/Variety & Fibre yield (q/ha) \\
\hline 1. & JRJ 610 & 14.25 \\
2. & JRJ 611 & 13.57 \\
3. & K-12 (Yellow) & 12.35 \\
\hline & S.E. $\pm(m)$ & 0.55 \\
& C.D. (5\%) & 1.64 \\
\hline
\end{tabular}

The significance of sca over gca suggests the importance of non-additive gene action in case of most of the characters studied except plant height where additive gene action was most important. Thus, considering per se performance, gca, sca and heterosis it can be concluded that the cross combinations, SUIN-056 $\times$ SUIN-074, SUIN-001 $\times$ SUIN-056 and K-12 (B) $\times$ SUIN-074 appeared superior for producing improved sunnhemp population. It suggests that choice of the parents, particularly for heterosis breeding, should be based on their specific 
combining ability test. Further, to exploit fully both additive and non-additive variances present in this population, random as well as chain crossing among the promising crosses was found effective to exploit both additive and fixable epistatic effects and at the same time can maintain considerable variability for further improvement by different selection cycles. It may also break some undesirable linkages and ultimately may be able to establish desirable rare segregants.

\section{References}

Coyle, G.G. and C.W. Smith. 1997. Combining ability for within-boll yield components in cotton (G. hirsutum L.). Crop Sci. 37: 1118-1122.

Griffing, B. 1956. Concepts of general and specific combining ability in relation to diallel crossing systems. Austr. J. Biol. Sci. 9: 463-493.

Hassan, G., Mahmood, G., Khan, N.U. and A. Razzaq. 2000. Combining ability in inter varietal crosses in upland cotton. Sarhad. J. Agric. 16: 407-410.

Khan, N.U., Hassan, G., Kumbhar, M.B., Parveen, A. Aiman, U., Ahmed, W., Shah, S.A. and Ahmed, S. 2007b. Gene action of seed traits and its oil content in upland cotton (G. hirsutum L.). SABRAO J. Breed. Genet. 39: 17-30.

Kundu, B.C. 1964. Sunnhemp in India. Proc. Crop Sci. Soc., Florida. 24: 396-404.

Liang, G.H. 1967. Diallel analysis of agronomic characters in grain sorghum, Sorghum vulgare pers. Can. J. Genet. Cytol. 11: 184-191.

Lukonge, E.P., Labuschagne, M.T. and L. Herselman. 2008. Combining ability for yield and fibre characteristics in Tanzanian cotton germplasm. Euphytica 161: 383-389.

Matzinger, D.F., Sprague, G.F. and C.C. Cockerham. 1959. Diallel cross of maize in experiments repeated over locations and years. Agron. J. 51: 346-350.

Muthu, R., Kandasamy, G., Raveendran, T.S., Ravikesavan, R. and M. Jayaramachandran. 2005. Combining ability and heterosis in yield traits in cotton ( $G$. hirsutum L.). Madras Agric. J. 92: 17-22.

Paroda, R.S. and A.B. Joshi. 1970. Genetic architecture of yield and components of yield in wheat. Ind. J. Genet. 30: 298-314.

Patil, V.D. and P.R. Chopda. 1981. Combining ability analysis over environments in diallel crosses of linseed (Linum usitatissimum L.). Theor. Appl. Genet. 60: 339-343.

Pradhan, S. K., Prakash, S. and S.K. Sarkar. 1999. Sunnhemp. In: Fifty years of research on jute and allied fibres agriculture. A golden jubilee volume 1948-1997. Central Research Institute for Jute and Allied Fibres, (I.C.A.R.), Barrackpore, W. B., pp. 203-209.

Rawlings, J.O. and D.L. Thompson. 1962. Performance level as criterion for choice of maize testers. Crop Sci. 2: 217-220.

Sprague, G.F. and L.A. Tatum. 1942. General versus specific combining ability in single crosses of corn. J. Amer. Soc. Agron. 34: 923-926. 